\title{
Keeping the Aged Engaged: A Quantitative Study of Lifelong Learning
}

\section{Steve Paydon \\ Waseda University \\ Robert Dilenschneider \\ Jichi Medical University}

\section{Reference Data:}

Paydon, S. \& Dilenschneider, R., (2020). Keeping the aged engaged: A quantitative study of lifelong learning. In P. Clements, A. Krause, \& R. Gentry (Eds.), Teacher efficacy, learner agency. Tokyo: JALT. https://doi.org/10.37546/JALTPCP2019-21

In this study we seek to confirm the findings of a preliminary qualitative study. We first discuss the concept of lifelong learning in Japan and self-determination theory (SDT). Second, using SDT as a framework, we present the findings from a qualitative study. Third, we discuss the findings obtained from a quantitative survey and how they build upon the findings of the qualitative study. Overall, the findings reinforce the notion that the three essential psychological needs in selfdetermination theory-competence, relatedness, and autonomy-are useful in keeping mature learners engaged in lifelong learning activities.

本研究は、質的予備研究の結果を確認しようとしている。まず、日本での生涯学習の概念と自己決定理論 (SDT)について議 論する。第二に、フレームワークとしてSDTを使用して、質的研究の結果について説明する。第三に、量的調査から得られた結 果と、その結果がどのように質的調査の結果に基づいているかについて説明する。全体として、これらの調查結果は、自己決定 理論における3つの本質的な心理的二ーズ(能力、関連性、自律性)が、成熟した学習者が生涯学習活動に参加するのに役立 つという概念を補強している。

his study explored the success behind two long-running lifelong learning classes in Japan. It was a quantitative study in which we sought to reaffirm and build on a previous qualitative study (Paydon \& Dilenschneider, in press) based on the same two classes. In this paper we first contextualize lifelong learning in Japan and provide an overview of Ryan and Deci's self-determination theory (SDT) as a conceptual framework to understand lifelong learning (2000). Next, the results of the first study are discussed as a foundation and rational for a follow-up quantitative study. We then look at the findings of the second study and discuss how they build upon the previous study. Finally, we summarize the findings as they relate to SDT.

\section{Overview of Lifelong Learning in Japan}

Lifelong learning in Japan dates back and is directly connected to the restructuring of Japanese society that came about as a result of the country's defeat in World War II (Ogden, 2010, p. 6). It starts with the Fundamental Law of Education that was introduced in 1947 (Gordon, 1998), out of which the Act for Adult Education developed in 1949. This concurrent act emphasized that learning occurs throughout one's lifetime with the aim of enabling citizens to contribute to the development of a democratic Japanese society (Ogden, 2010, p. 6). The lifelong learning concept in Japan has developed with increasing support ever since. Presently, the Ministry of Education, Culture, Sports,

Science and Technology (MEXT, 2018) recognizes the growing importance of lifelong learning and defines their image of a society supporting lifelong learning as "a society in which everyone can learn anywhere and at any time in their lives and appropriately utilize that learning to cultivate their own individuality and lead a fulfilling life" (MEXT, 2018).

\section{Self-Determination Theory}

Self-determination theory (SDT) is concerned with the intrinsic and extrinsic factors that provide motivation and well-being. The theory identifies three innate psychological needs which, when satisfied, lead to enhanced self-motivation and mental health.

However, when these needs are obstructed, a sense of motivation and well-being is 
diminished. Ryan and Deci (2000) identify these needs as relatedness, competence, and autonomy (p. 68).

To paraphrase part of Ryan's opening speech at the 5th Conference on SelfDetermination Theory (2013), relatedness refers to the need to feel cared for and connected to others. It has to do with a sense of belonging, and in this way compliments Baumeister and Leary's (1995) theory of the need to belong. Ryan (2013) explained that when the need for relatedness is satisfied, individuals feel that they are important to the people that surround them. Competence refers to the need for people to feel effective in their environment, which is particularly the case with regard to things they value. Autonomy refers to the need for individuals to feel a sense of self-endorsement. When a person is autonomous they tend to be enthusiastic because they feel empowered in their choices.

As Ryan and Deci (2000) explained, "Human beings can be proactive and engaged or passive and alienated according largely to the social conditions in which they develop and function" (p. 68). By applying SDT to the classroom, social environments can be created that optimize students' development, performance, and well-being (Ryan \& Deci, 2000 , p. 68). As such, SDT has been a major influence in the two lifelong-learning classes at the center of this study, and this paper uses this theory with its three psychological needs as a framework to investigate what makes these two classes successful.

\section{Background}

\section{Participants}

The two lifelong learning English classes at the center of this research are supported by a local university in Yokohama. These classes had been in place for 15 years at the time of the first study in July of 2018. Each year the course is broken up into two 12-week semesters: one in the spring and one in the fall. Both classes consist mainly of Japanese participants in their 50s, 60s, and 70s with a broad range of life experience, interests and hobbies. The students live in and around Yokohama, which is about 30 minutes south of Tokyo. The classes are voluntary, suggesting that students are intrinsically motivated.

The classes originally began as two similar groups of mostly mixed-level, middle-aged and retired adults taught at two different time slots. Therefore, due to their age and range of life experiences, the participants who took part in these studies are referred to as mature learners. Over time, the two classes gradually settled into two separate levels: a low-level class (hereafter referred to as LL) in the afternoon and a high-level class (hereafter referred to as HL) in the evening. As the class levels changed, the course descriptions also changed to reflect the needs of each group of students. For example, the title of the LL class became Fun English and the course description states that the class is conducted in 70\% English and 30\% Japanese. In contrast, the HL class was retitled English Discussion and the course description states that the class is conducted $100 \%$ in English. The effect of the differences in class titles and the course descriptions consequently influenced the expectations of new students joining the groups. For instance, students interested in English as a hobby or fun activity tended to register for the LL class, whereas students with comparatively higher expectations and a more serious approach to English tended to register for the HL class.

\section{Initial Findings}

The two lifelong learning English classes have a high rate of returning students. Students' feedback from this quantitative study and the corresponding qualitative study (Paydon \& Dilenschneider, in press) aim to examine how to further enhance these classes with reference to SDT. One of the tenets of SDT, for example, is that when teachers focus on satisfying the innate psychological human needs for relatedness, competence, and autonomy, they can create social environments that foster the potential for personal growth and motivation (Ryan \& Deci, 2000). When these needs are addressed in lifelong learning classes for mature students, a rewarding social environment can be created that can influence an increase in engagement.

In regards to relatedness, there appeared to be high levels of satisfaction in both classes in response to multiple questions. For example, when the students were asked directly how they felt about the relationships they had in class, they responded very favorably. In particular, when asked about what kinds of activities they liked, students in both classes indicated that they enjoyed activities that allowed them to change partners and interact often.

The need for competence was also reflected in both classes. The qualitative study found that both groups wanted to study and improve their English. They also responded that they were mostly concerned with self-expression, and that they struggled with a broad range of linguistic skills. However, the clear majority of students in the LL class expressed a need for a textbook so that they could preview the content, have a reference in front of them during class, and then review later at home. This desire for a textbook seemed to emphasize their to emphasize their need for competence.

Finally, the need for autonomy appeared to be different between the two classes. For instance, in stark contrast to the LL class, the HL class wanted to choose their own discussion topics rather than use a textbook. This desire to choose the topics discussed in the course seemed to indicate that the need for autonomy was higher for the HL class. 
In sum the qualitative study (Paydon \& Dilenschneider, in press) found that, although students from both classes thought the need for relatedness was important, the manner in which the two groups desire the needs for competence and autonomy was different. Therefore, based on these findings, the purpose of the follow-up quantitative study was to further examine how the comments from the initial qualitative study might relate and compare with responses for a quantitative survey.

\section{The Quantitative Study}

The purpose of the follow-up quantitative study was to examine how the comments from the qualitative questionnaire used the first study compare with responses to a quantitative survey. Specifically, the second study aimed to quantifiably observe the importance of the three SDT needs in the order of competence, relatedness, and autonomy, as well as the students' motivation to continue lifelong learning.

\section{Research Question}

Therefore, the research question with four parts is as follows:

RQ. Is there an observational difference between the LL and HL groups in learners need for competence, relatedness, autonomy and their motivation regarding lifelong learning?

\section{Participants}

The second study consisted of the same two classes from the first study. Table 1 shows the number of participants in each age group for both classes.

Table 1: Age and Number of Participants in Lifelong Learning Classes

\begin{tabular}{ccccccc}
\hline Group & $40 s$ & $50 s$ & $60 s$ & $70 s$ & $80 s$ & Total \\
\hline LL & 2 & 6 & 9 & 3 & 2 & 22 \\
HL & 0 & 3 & 4 & 6 & 1 & 14 \\
\hline
\end{tabular}

Note. $\mathrm{LL}=$ low-level group, $\mathrm{HL}=$ high=level group.

\section{Materials}

The survey created for the second study was composed of five different sections to investigate participants' background and opinions concerning competence, relatedness, autonomy and lifelong learning (Appendix A). The first section asked participants for some basic background information; the remaining four sections of the survey consisted of a total of 18 questions that were based on a 5-point Likert scale from strongly disagree to strongly agree. Based on this scale, participants could report their level of agreement concerning the issues of competence, relatedness, autonomy and lifelong learning in relation to the course. The survey was initially written in both English and Japanese offering students' the choice of language to answer in, and serving as a reference between the languages.

\section{Procedure}

Near the end of the spring semester, the survey was administered to both the LL and HL classes. All the participants gave informed consent, and the project was cleared with the university's administration. Participants were encouraged to be honest with their responses and were assured that personal identity and answers would remain anonymous. After about 15 minutes, the instructor collected the surveys and the participants were thanked for their involvement.

Results

\section{Competence}

The first set of questions in the survey were aimed at measuring students' need for competence. Results for the five competence questions (Q5-Q9) are shown in Figure 1.

The responses to all five competence questions were higher for the HL compared to the LL. The greatest difference between the two groups was in response to Q6 ("I feel comfortable communicating in English with one other student," $4.07-3.04=1.03$ ) and the smallest difference was in response to Q8 ("I feel comfortable speaking English in front of all members of the class," $3.28-2.90=.38$ ). Overall, the average difference between the two groups for the five competence questions was $.76(.62+1.03+.81+$ $.38+.97=38.1 \div 5=.76)$. These results suggest that the HL class was more comfortable communicating in English than the LL class. 


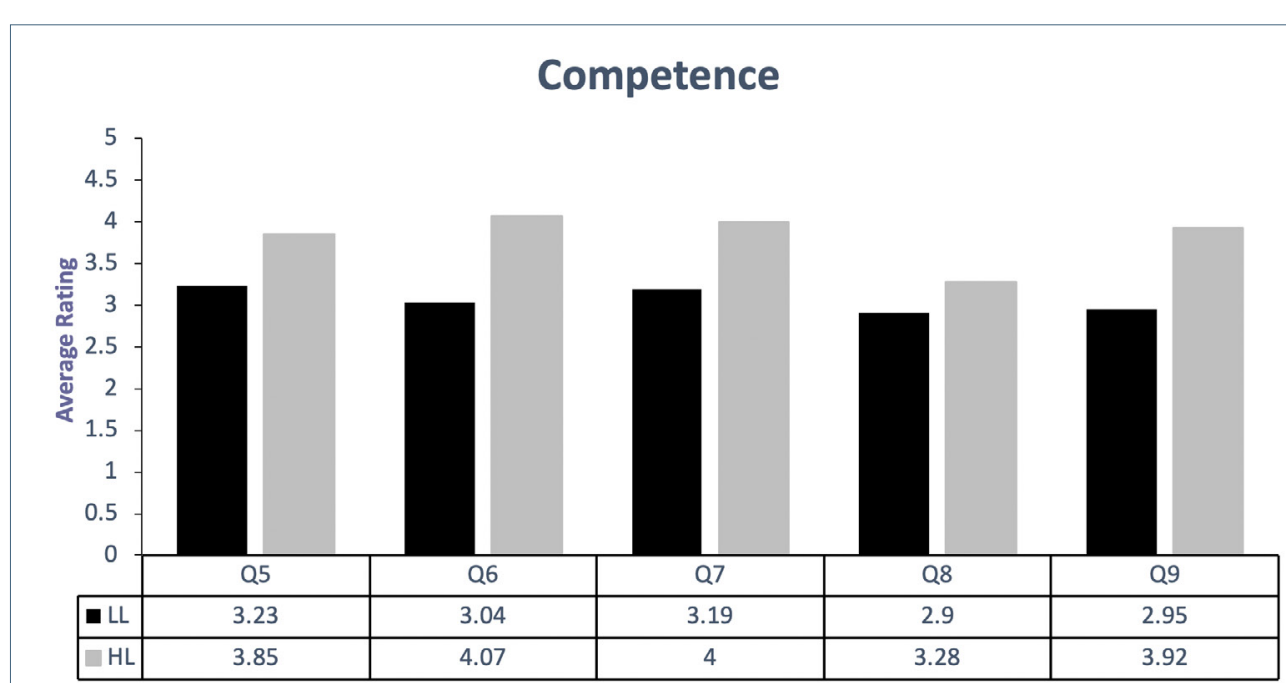

Figure 1. Average agreement rating for competence survey questions. Q5: I feel comfortable communicating in English with the teacher. Q6: I feel comfortable communicating in English with one other student. Q7: I feel comfortable communicating in English in groups in our class. Q8. I feel comfortable speaking in front of all the members of our class. Q9: I feel comfortable communicating in English with strangers. $\mathrm{LL}=$ low-level group; $\mathrm{HL}=$ high-level group. 1 = strongly disagree; $5=$ strongly agree.

\section{Relatedness}

The second set of questions in the survey were relatedness-based questions aimed at measuring how the students felt about the relationships they had with the other students in their respective classes. Results for the five relatedness questions (Q10-Q14) are shown in Figure 2.

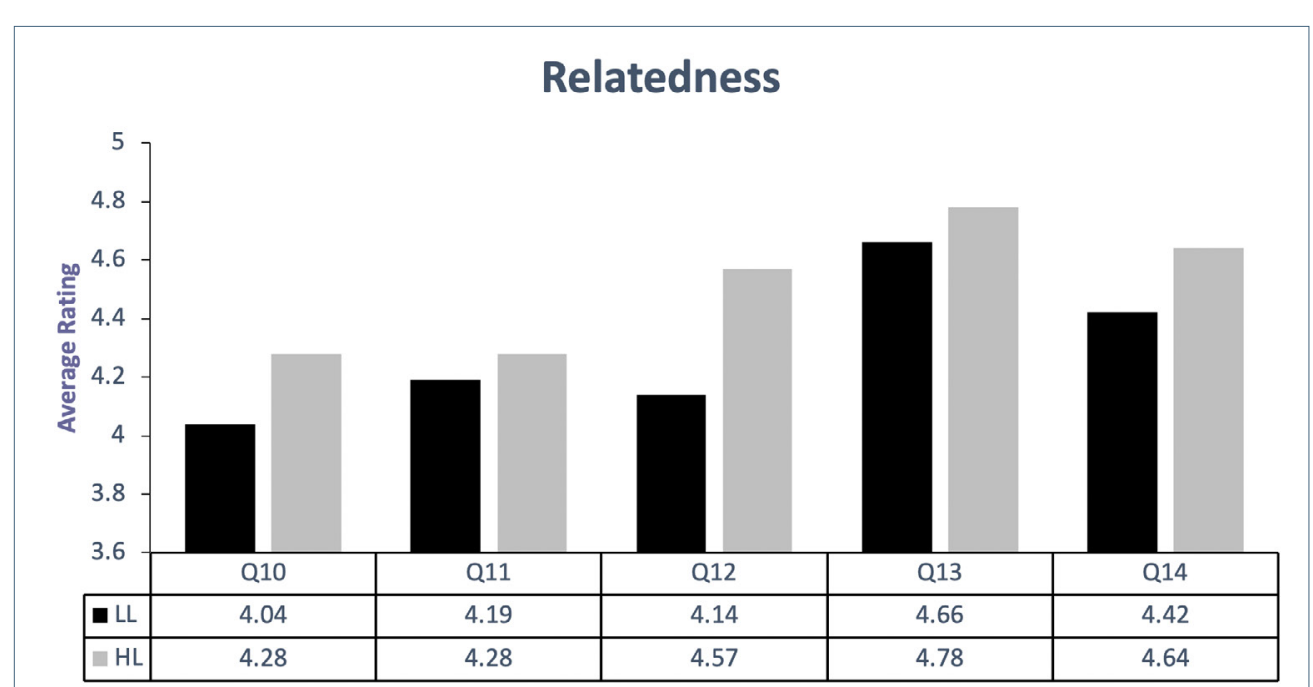

Figure 2. Average agreement rating for relatedness survey questions. Q10: I look forward to speaking English in class. Q11: I look forward to talking with my teacher in class. Q12: I look forward to speaking English with my classmates in class. Q13: I think there is a cozy atmosphere (雾囲気がいい) in our class. Q14: I think the students are cooperative in creating a good atmosphere. $\mathrm{LL}=$ low-level group; $\mathrm{HL}=$ high-level group. 1 = strongly disagree; 5 = strongly agree.

The responses for all five relatedness survey questions were higher for the $\mathrm{HL}$ compared to the LL. The greatest difference between the two groups was in response to Q12 ("I look forward to speaking English with my classmates,".43), and the smallest difference was in response to Q11 ("I look forward to talking with my teacher in class,".09). The average difference between the two groups for the five relatedness questions was $.22(.24+.09+.43+.12+.22=.71 \div 5=.22)$. These results suggest the HL class was more comfortable with interpersonal relationships they shared with other students than the LL class.

\section{Autonomy}

The third set of questions in the survey were related to autonomy and designed to measure students' desire to have control or direction in their learning. Results for the three autonomy questions (Q15-Q17) are shown in Figure 3. 


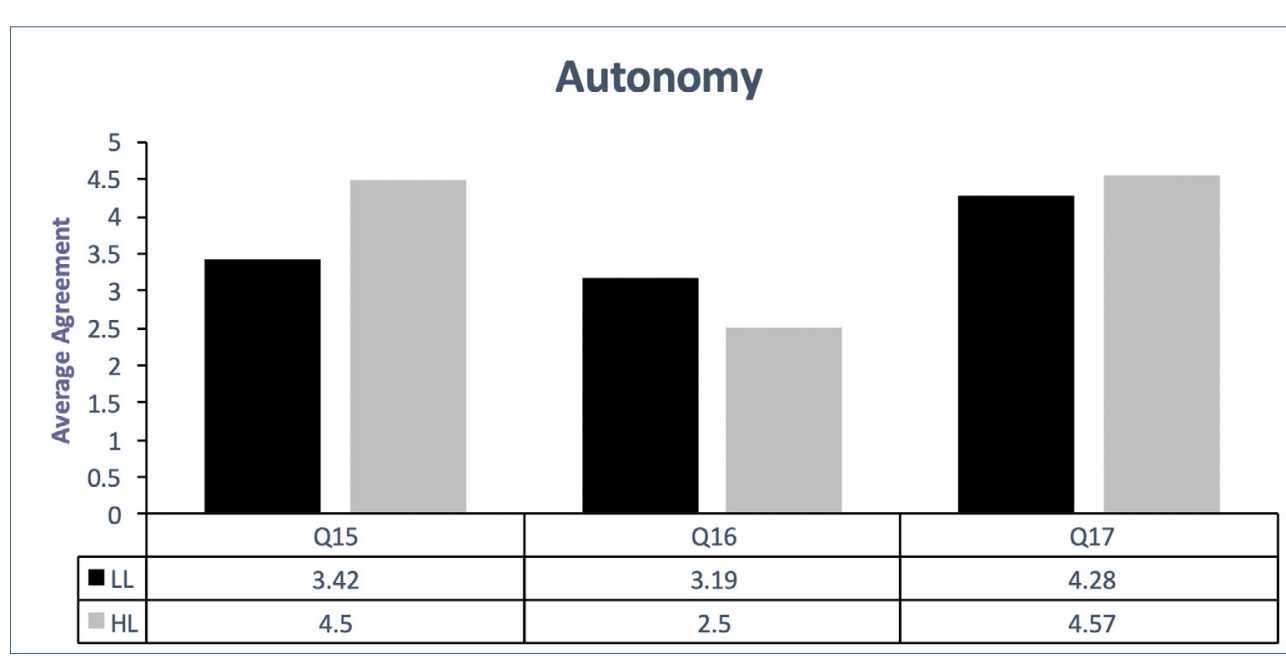

Figure 3. Average agreement rating for autonomy survey questions. Q15: I would like the teacher to create teaching materials on topics selected by the students. Q16: I would like to follow the topic and exercises from the textbook. Q17: I think the teacher respects our opinions about the class. $\mathrm{LL}=$ low-level group; $\mathrm{HL}=$ high-level group. 1 = strongly disagree; 5 = strongly agree.

The responses of the two groups to the three survey questions related to autonomy were found to have an inverse relationship. For example, the HL class reported a higher agreement average for Q15 ("I would like the teacher to create teaching materials on topics selected by students," $4.5>3.4$ ) and the LL class reported a higher agreement for Q16 ("I would like to follow the topics and exercises from a textbook," $3.2>2.5$ ). However, for Q17 ("I think the teacher respects our opinions about the class,") the HL class (4.6) and the LL class (4.3) were both in agreement. These results seem to confirm the findings of the first study that there was a difference between the need for competence and autonomy, and that the students appreciated being given a choice as to how they studied.

\section{Lifelong Learning}

The last set of questions in the survey were related to lifelong learning and designed to measure students' motivations for attending the course. Results for the five lifelong learning questions (Q18-Q21) are shown in Figure 4.

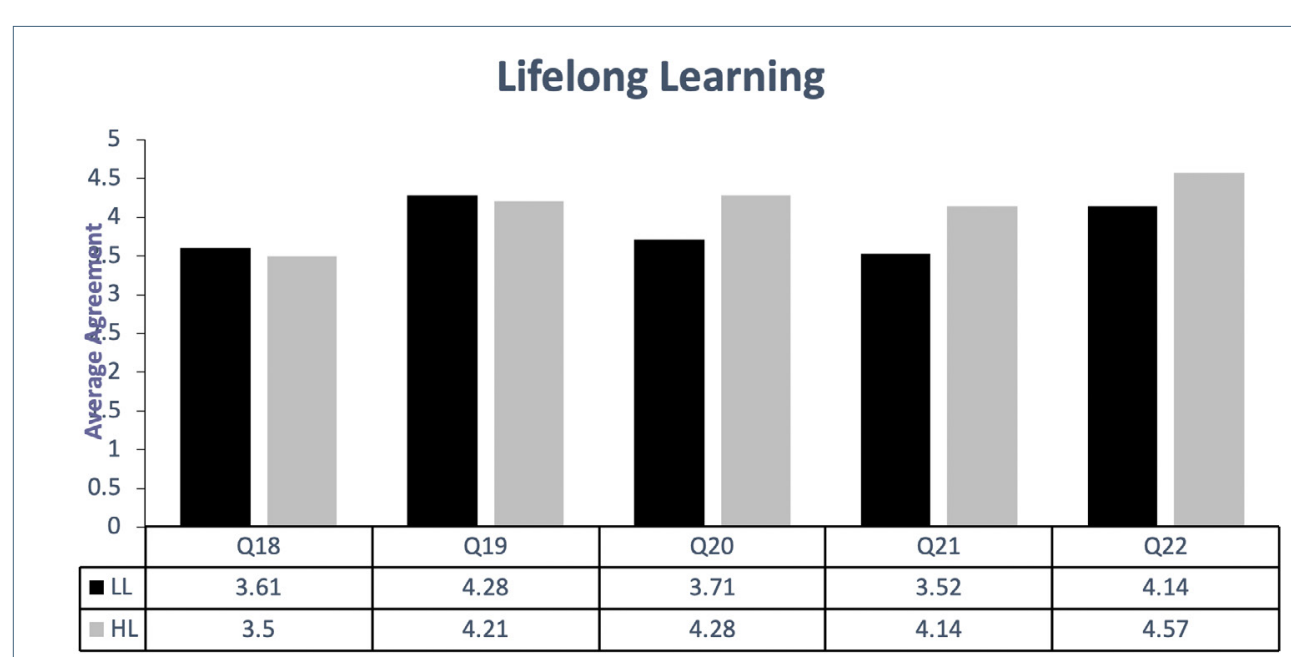

Figure 4. Average agreement rating for lifelong learning survey questions. Q18: I study English because it is useful for everyday life. Q19: I study English because it is fun and interesting. Q20: I study English so that I do not forget what I have learned. Q21: I study English because I think it is beneficial to my mental health and well-being. Q22: I think my relationship with my classmates is beneficial for my mental health and well-being. LL = low-level group; $\mathrm{HL}$ = high-level group. 1 = strongly disagree; 5 = strongly agree.

The responses for the five lifelong learning survey questions are somewhat divided between the two groups. For instance, both the LL and HL classes reported similar agreement ratings for Q18 ("I study English because it is useful for everyday life," 3.6, 3.5) and for Q19 ("I study English because it is fun and interesting," 4.3, 4.2). However, the HL class reported noticeably higher agreement ratings for Question 20 ("I study English so that I do not forget what I have learned," $4.2>3.7$ ), Q21 ("I study English because I think it is beneficial to my mental health and well-being," $4.2>3.5$ ), and for Q22 (I think my relationship with my classmates are beneficial for my mental health and well-being," $4.6>4.1)$. As a result, these findings suggest that, compared to the LL class, students in the HL class sought more of a mental challenge and were slightly more motivated to participate in the language class as a way of maintaining their mental faculties and social skills. 


\section{Discussion}

This quantitative follow-up study confirms and builds on the findings established in the qualitative study (Paydon \& Dilenschneider, in press). Both studies are concerned with applying the factors of SDT in the classroom in order to develop conditions that are conducive to language learning for mature students. These conditions are achieved by aiming to satisfy the students' innate need for competence, relatedness and autonomy as defined in SDT.

\section{Competence}

With regard to competence, SDT posits that motivation can be enhanced when the need for feeling effective in one's environment is satisfied (Ryan \& Deci, 2000). The initial study suggested that the need for competence was important for both classes. This study confirmed that, compared to the LL students, the HL students, whether with one individual, in groups or with strangers, were more comfortable communicating in all situations. This finding suggests that LL students may feel their language abilities it may be somewhat limited and therefore they should gain confidence by first communicating in pairs before they graduate to speaking in larger groups.

\section{Relatedness}

With regard to relatedness, SDT also posits that motivation can be enhanced when the need for feeling connected to others is satisfied. (Ryan \& Deci, 2000). In the initial study, both groups clearly stated the importance of the positive interpersonal relationships that they had developed in their respective classes. This study supports the initial findings and further reveals that interpersonal relationships appeared to actually be more important than the act of speaking English itself. Although students in both classes indicated that they looked forward to speaking English, their responses were relatively more favorable with regard to speaking English with their classmates, and most favorable when communicating in an inviting or cozy atmosphere (雾囲気がいい). These findings suggest that cultivating a comfortable learning environment can help promote communication.

\section{Autonomy}

With regard to autonomy, SDT further posits that motivation can be enhanced when students feel empowered (Ryan \& Deci, 2000). The previous study found that, although autonomy was important for all students, it was much more pronounced in the HL group. The findings from this follow-up quantitative study seems to confirm that, in terms of language support, the LL class preferred to have the guidance of a textbook and the HL students had a clear preference for control of the content.

\section{SDT and Lifelong Learning}

This study aimed to investigate the students' motivations for participating in lifelong learning courses. Although responses from both groups were quite positive, the $\mathrm{HL}$ group seemed to place more importance on attending classes in order to maintain their memory, mental health and well-being. There appear to be two possible explanations for this difference in emphasis. First, the average age for the HL group (64) was a bit higher than the LL group (58). Therefore, compared to the LL group, the HL group may have been more concerned with the need to maintain their mental faculties and social abilities. Secondly, as mentioned above, the two separate course descriptions may have had some influence on what the students expected from a class. For example, in the case of the LL class, the class title and course description created the expectation of having fun, and this emphasis seems to have resulted in slightly higher responses from the LL group to Q19. However, the course description for the HL class clearly stated that classes were $100 \%$ in English. Therefore, it seems likely that students registering for that class expected to be intellectually challenged. Hence, given the choice, the HL group might have been comparatively more focused on learning for mental health and well-being than on having fun. Nevertheless, all responses to the lifelong learning questions were positively in favor of the statements suggesting that, at least for these two particular groups, this lifelong learning class was successfully providing an opportunity for mature learners to remain mentally stimulated and engaged in society. Moreover, focusing on human needs as defined by SDT seemed to be effective at keeping students like these engaged in a lifelong-learning program.

\section{Conclusion}

In conclusion, SDT can assist teachers in creating motivational classroom environments in which mature-aged learners can feel comfortable being challenged (competence), a sense of belongingness (relatedness), and exercise some kind of control (autonomy).

The initial study also revealed what appeared to be a difference between the need for autonomy and control linked to the students' level of ability. This study confirmed this finding and identified a further difference between the need for competence and relatedness also linked to student ability. These findings might have potential benefits 
when applied to classroom management techniques and course design.

With regard to the concept of lifelong learning itself, this study suggests that the older students are more interested in language classes to maintain their memory, mental health and well-being. Therefore, the concept of lifelong learning seems to be fulfilling its role in keeping the aged mentally stimulated and engaged in society.

This study has demonstrated that the SDT factors of competence, relatedness and autonomy are worth examining with mature learners because they can be beneficial in keeping them engaged in lifelong-learning classes. This is particularly the case in Japan because its aging population continues to increase and live longer. Attention to these needs can help teachers create motivational classroom environments where mature students can feel appropriately challenged and comfortable communicating their thoughts and ideas in a manner that best suits the ways they like to learn.

\section{Bio Data:}

Steve Paydon is from Australia and has lived and taught in Japan for over 20 years. He teaches ESL at Waseda University and Lifelong Learning classes to mature-aged students in Yokohama, Japan.

Robert Dilenschneider, Ed.D. is from the United States and has lived and taught in Japan for over 20 years. He teaches ESP to medical students at Jichi Medical University and ESL at Rikkyo University.

\section{References}

Baumeister, R \& Leary, M. (1995). The need to belong: Desire for interpersonal attachment as a fundamental human motivation. Psychological Bulletin, 117, 497-529. https://doi. org/10.1037/0033-2909.117.3.497

Gordon, B. (1998). Lifelong learning in Japan. Retrieved June 2018 from http://www.bill-gordon.net/ papers/lifelrn.htm

MEXT. (2018). The significance of lifelong learning. Retrieved June, 2018 from http:// www.mext.go.jp/en/policy/education/lifelonglearning/title01/detail01/1373921.htm

Ogden, C. O. (2010). A brief overview of lifelong learning in Japan. The Language Teacher, 34(6), 5-13. https://doi.org/10.37546/JALTTLT34.6-1

Ryan, R., \& Deci, E. (2000). Self-determination theory and the facilitation of intrinsic motivation, social development, and well-being. American Psychologist, 55(1) 68-78. https://doi.

org/10.1037/0003-066X.55.1.68
Ryan, R. (2013, July 1). Highlights of the opening remarks from the 5th Conference on Self-

Determination Theory. Retrieved from https://www.youtube.com/watch?v=C4E10e8zlkw\&t=319s

Paydon, S. \& Dilenschneider, R. (in-press) The Language Teacher.

\section{Appendix}

\section{Questionnaire}

Thank you for attending this class. We appreciate your feedback to improve your experience. Please complete the following survey. Your opinion is highly appreciated and your identity and answers will remain anonymous.

\section{Background:}

1. Gender: Male Female

2. Age:

3. Since when have you been coming to this class?

4. What motivates you to keep coming?

To answer the following questions, circle your answer number on the scale below.

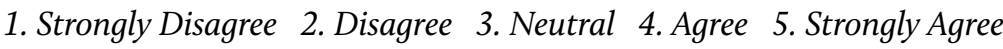

\section{Competence}

5. I feel comfortable communicating in English with the teacher.

6. I feel comfortable communicating in English with one other student.

7. I feel comfortable communicating in English in groups in our class.

8. I feel comfortable to speaking English in front of all the members of our class.

9. I feel comfortable communicating in English with strangers.

Relatedness

10. I look forward to speaking English in class.

11. I look forward to talking with my teacher in class.

12. I look forward to speaking English with my classmates in class.

13. I think there is a cozy atmosphere in our class. 
14. I think the students are cooperative in creating a good atmosphere.

\section{Autonomy}

15. I would like the teacher to create teaching materials on topics selected by the students.

16. I would like to follow the topics and exercises from a textbook.

17. I think the teacher respects our opinions about the class.

\section{Lifelong Learning}

18. I study English because it is useful for everyday life.

19. I study English because it is fun and interesting.

20. I study English so that I do not forget what I have learned.

21. I study English because I think it is beneficial to my mental health and well-being.

22. I think my relationship with my classmates are beneficial for my mental health and well-being

12345

12345

12345

12345

12345

12345

12345

12345

\section{Japanese Version}

このクラスにご参加いただきありがとうございます。経験を向上させるために、私たちはあなたのフィ ードバックをとても感謝します。以下の調査を完了してください。あなたの意見は非常に高く評価さ れており、あなたのアイデンティティと答えは匿名のままです。

バックグラウンド

1. 性別: 男性 女性

2. 年齢:

3.いつからこのクラスに通っていますか。

4. ずつと通い続けているのは、なぜですか。
能力について

5. 私は先生と英語で気軽に話せると思います。

6. 私はほかの学生と英語で気軽に話せると思います。

7. 私はクラスのグループで英語を気軽に話せると思います。

8. 私たちのクラスのメンバー全員の前で英語を話しやすいです。

9. 私は誰か始めて会った人と英語で気軽に話せると思います。

$\begin{array}{lllll}1 & 2 & 3 & 4 & 5\end{array}$

$\begin{array}{lllll}1 & 2 & 3 & 4 & 5\end{array}$

$\begin{array}{lllll}1 & 2 & 3 & 4 & 5\end{array}$

$\begin{array}{lllll}1 & 2 & 3 & 4 & 5\end{array}$

$\begin{array}{llllll}1 & 2 & 3 & 4 & 5\end{array}$

\section{関係性について}

10. 私はクラスで英語を話すのを楽しみにしています。

11. 私はクラスで先生と話すのを楽しみにしています。

12. クラスメートと一緒に英語を話すのを楽しみにしています。

$\begin{array}{lllll}1 & 2 & 3 & 4 & 5\end{array}$

$\begin{array}{lllll}1 & 2 & 3 & 4 & 5\end{array}$

13.このクラスは雾囲気がいいと思います。

14. 生徒たちは良い雾囲気を作るのに協力的であると思います。

$\begin{array}{lllll}1 & 2 & 3 & 4 & 5\end{array}$

$\begin{array}{llllll}1 & 2 & 3 & 4 & 5\end{array}$

\section{自主性について}

15. 生徒が選んだトピックについて教師に教材を作ってもらいたいです。１ 1273445

16. 私はテキストに従って勉強したいと思います。

17. 先生は私たちのクラスについての意見を尊重してくれていると 思います。

生涯学習について

18. 日常生活に役立つので英語を勉強します。 123345

19. 楽しくて面白いので英語を勉強します。

$\begin{array}{llllll}1 & 2 & 3 & 4 & 5\end{array}$

20. 私は、今までに学んだことを忘れないように英語を勉強しています。

$\begin{array}{lllll}1 & 2 & 3 & 4 & 5\end{array}$

21. 私は精神的健康と幸福に有益であると思うので英語を勉強します。

22. 私のクラスメートとの関係は精神的健康と幸福にとって有益であると 思います。

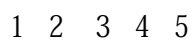

$\begin{array}{lllll}1 & 2 & 3 & 4 & 5\end{array}$

以下の質問に答えるために、あなたの答えの数を以下の尺度で丸にしてください。

1. 強く同意しない 2. 同意しない 3. 中性 4. 同意する 5 . 強く同意します 